\title{
Pregnancy Act:
}

\section{Some Empirical findings}

\author{
MC Engelbrecht \\ $M A$ \\ Researcher
}

Centre for Health Systems Research \& Development University of the Free State

\&

AJ Pelser

Ph.D

Associate Professor

Department of Sociology

University of the Free State

Bloemfontein

$\&$

Charles Ngwena
LLM
Associate Professor

Faculty of Law

Vista University, Bloemfontein Campus

$\&$

\section{HCJ van Rensburg D.Phil \\ Director}

Centre for Health Systems Research \& Development University of the Orange Free State

\section{Abstract}

The Choice on Termination of Pregnancy Act of 1996 substantially liberalised abortion law. Whilst a substantial number of terminations of pregnancies (TOPs) have already been performed in terms of the new Act, it has also surfaced that an array of factors of various kinds may impede its further implementation and operation. A study was undertaken to determine the nature and extent of any such impediments to the implementation of the Choice on Termination of Pregnancy Act. More specifically a survey was conducted amongst a sample of 75 women who had undergone a TOP since the implementation of the Act; health professionals and social workers who provide TOP services $(n=16)$; and health professionals and social workers who are in a position to refer women to TOP facilities $(n=63)$. Overall, the clients were well treated at the TOP facilities, and were satisfied with the service given to them. However, post-counselling and to a lesser extent pre-counselling, is lacking. Counselling is important as a considerable proportion of the clients suffered from emotional feelings usually associated with depression and/or self-reproach before and after the termination procedure. Furthermore these clients did not usually discuss their termination with family members. TOP service providers were dissatisfied with the TOP facilities, especially the insufficient number of consultation and counselling rooms. Health care workers in a position to refer clients to TOP facilities were not always willing to do so, thereby obstructing the referral system. In the main, it is recommended that the entire TOP procedure should be done at clinics/inospitals so that clients will not have to do inductions at home, more trained staff should be available, facilities should be adequate and accessible, and there should be psychological support for staff.

\section{opsomming}

Die "Choice on Termination of Pregnancy Act" van 1996 het verreikende veranderinge in aborsiewetgewing meegebring. Terwyl 'n groot aantal swangerskappe reeds ingevolge die Wet getermineer is, het dit ook geblyk dat verskeie faktore die verdere implementering en werking daarvan kan belemmer. Die onderhawige navorsing het gepoog om die aard en omvang van sulke stuikelblokke te bepaal. 'n Opname is gedoen onder 75 vroue wat sedert die implementering van die Wet ' $n$ aborsie ondergaan het, asook gesondheidswerkers wat die diens verskaf $(n=16)$ en diegene wat in ' $n$ posisie is om vroue na sulke fasiliteite te verwys $(n=63)$. Oor die algemeen is die kliënte goed behandel by die fasiliteite en is hulle tevrede met die diens wat hulle ontvang het. Postberading, en tot ' $n$ mindere mate voorafberading, was egter ' $n$ probleem. Die behoefte aan berading blyk duidelik uit die feit dat ' $n$ beduidende proporsie van die kliënte gebuk gegaan het onder emosionele gevoelens wat gewoonlik met depressie en/of selfverwyt geassosieer word. Hierdie vroue bespreek ook nie dikwels die terminering van hul swangerskappe met 
gesinslede nie. Gesondheidswerkers was ontevrede met die fasiliteite, veral die tekort aan konsultasie- en beradingskamers. Diegene in 'n posisie om kliënte na fasiliteite te verwys, is nie altyd gewillig om dit te doen nie en belemmer sodoende die verwysing-stelsel. Die belangrikste aanbeveling deur die kliënte was dat die hele termineringsprosedure by klinieke/hospitale gedoen moet word, sodat induksies nie tuis gedoen hoef te word nie. Aanbevelings vir die gladde funksionering van die diens het onder andere ' $n$ vermeerdering van gekwalifi-seerde personeel, genoegsame en toeganklike fasiliteite, asook sielkundige ondersteuning vir personeel ingesluit.

\section{Introduction}

For thousands of years, abortion has been used as a form of birth control in many societies and South Africa is no exception. In the middle of the $19^{\text {in }}$ century, British officials in the Eastern Cape reported that abortions were performed on all classes of African women. It was seen as an acceptable way to deal with problematic pregnancies. Some chiefs in the Eastern Cape, for instance, were expected to force an adulterous wife to induce a miscarriage. A folk recipe for abortion was included in a $20^{\text {th }}$ century Afrikaner home remedy book; herbs and chemists' preparations were widely used. Surgical procedures became increasingly available from the late $19^{\text {th }}$ century, mostly for white women (SAMJ 1997:417). Religious tinges attached to abortion included $19^{\text {th }}$ century missionaries teaching African women that abortion was a serious sin. Cultural issues also come to the fore: rural Pedi and Tsonga men believed that if a woman had an abortion, there would be no rain. African women who had abortions were seen as being deviant or witches (Goosen \& Klugman 1996: 336-338).

During the colonisation of South Africa, Roman-Dutch Law was introduced and with it came the first legal references to the general law on abortion. Abortion was criminalised, except where it was performed to save the life of the woman. This exception became known as the "defence of therapeutic abortion". Unfortunately common law was not able to clearly delineate its boundaries. It was uncertain, for example, whether the exception was only applicable if an abortion would save the woman's life or also if it would protect her from physical or mental injury (Ngwena, 1998: 4). In 1975 the Abortion and Sterilisation Act was passed to clarify the law on abortion. However, the Act was seen as being unduly restrictive of legal abortion. It was replaced in 1996 by the Choice on Termination of Pregnancy Act, which sought to render legal abortions more easily obtainable by all women in South Africa.

This article reports on the findings of a study aimed to determine the nature and extent of impediments to the implementation of the Choice on Termination of Pregnancy Act of 1996. The article documents the findings of a survey conducted among users and providers of termination of pregnancy (TOP) services in the Free State and identifies the problems, constraints and impediments that they encountered while accessing TOP services. The next phase of this study will be to develop an intervention strategy in the Free State Province to assist policy makers, managers and health providers in overcoming problems, constraints and impediments to the implementation and operation of the Act.

\section{The background to the Choice on}

\section{Termination of Pregnancy Act (1996)}

The Abortion and Sterilisation Act of 1975 was heavily criticised for being unduly restrictive of legal abortion (Sarkin-Hughes \& Sarkin-Hughes 1990: 372-87; Felder 1993; Hanson \& Russell 1993: 500-24; Ngwena 1998: 32-64). Stringent restrictions on access to legal abortions had the undesired effect of encouraging illegal or 'backstreet' abortions, particularly among the Africans and the poor. Literature reflects that mainly white, urban, middle-class women "qualified" for legal abortion under the 1975 Act. During the period that the Act was operational, an average of $800-1200$ women qualified annually for a legal abortion. Of these women two thirds were from white, urban, middle class backgrounds (Strauss 1991). On the other hand, upwards of 44000 mostly African and poor women, with limited access to family planning services, had recourse to illegal abortions each year. According to the Medical Research Council (SAIRR 1997: 492), this figure is still an underestimate, and the number of illegal abortions could have been as high as 120000 each year. Walker (1996: 43-67) stated that back-street abortions were conducted every two minutes. By virtue of being conducted outside official health care facilities, in unhygienic conditions, and often by unqualified persons, illegal abortions came with an inevitable extra toll on health and mortality. Annually, illegal abortions accounted for approximately 33000 surgical procedures as remedial treatment, and 400 deaths. Not only did illegal abortions cause much human suffering, they also imposed a financial burden on the state; approximately R18,5 million was annually spent to treat infections and other complications associated with illegal abortions. The ANC-led government embarked on a process of reforming abortion law. To drive the reform process an ad hoc parliamentary Select Committee was established to inquire into whether the 1975 Act was operating satisfactorily, and if not, to suggest an alternative (Goosen \& Klugman 1996: 339). But as the shortcomings of the 1975 Act were well known, the issue was not whether but instead how to reform the 1975 Act (Ngwena 1998: 10-11). Eventually the Committee recommended that the Abortion and Sterilisation Act of 1975 be replaced by a new Act (Goosen \& Klugman 1996: 339; Ngwena 1998: 12)

\section{The Choice on Termination of Pregnancy Act (1996)}

In November 1996 a new law, the Choice on Termination of Pregnancy ACt, was passed and took effect from 1 February 1997 (Act no 92 of 1996). The Act's provisions reflect in large part the recommendations of the Select Committee, albeit with some compromises that were a result of some parliamentary opposition to the original Bill. In essence the new Act promotes reproductive rights and extends freedom of choice by offering every woman the right to choose whether to have an early, safe and legal TOP according to her individual beliefs.

The grounds for abortion, especially during the first 12 weeks of pregnancy, have been substantially liberalised. Abortion on request is now available during the first 12 weeks of pregnancy. During this period, the pregnant woman is not required to give any reasons for wanting to have an abortion. A medical practitioner as well as a midwife who has undergone prescribed training, may perform the abortion during this gestation period. From the $13^{\text {th }}$ to the $20^{\text {th }}$ week, however, abortion requires more than the mere request and the consent of the woman. Abortion is available: (i) if the continued pregnancy would pose a risk of injury to the woman's physical/mental health; or (ii) if there exists a substantial risk that the foetus would suffer a severe physical/mental abnormality; or (iii) if the pregnancy resulted from rape or incest; or (iv) if the continued pregnancy would significantly affect the social or economic well-being of the woman. Abortion is also available from the $20^{\text {th }}$ week up to term, providing a medical practitioner, after consultation with 
a registered midwife, is of the opinion that continued pregnancy would: (i) endanger the life of the woman; or (ii) result in severe malformation of the foetus; or (3) pose a risk of injury to the foetus. The essential aim of the new Act is to break with the regime under the $1975 \mathrm{Act}$ and render legal abortion more easily and readily obtainable by all women in South Africa.

\section{Controversy surrounding the new Act and implications for implementation}

The Choice on Termination of Pregnancy Act, like any measure that has heavy moral undertones, has resulted in much controversy (The Star 20.09.1996; 06.10.1996; 16.10.1996). Health care providers who are opposed to abortion and regard the Act as unacceptably permissive, are one of the many impediments that have the potential of seriously frustrating the implementation and operation of the Act. Doctors working in a community hospital in KwaZulu-Natal raised objections to the TOP Act before it was passed. They indicated that abortion on demand was a violation of not only the sanctity of human life but also of their moral and professional responsibility to preserve life (Hardy, Gilpin, Stead, van Andel \& Somasumeran, 1996: 1433). A survey conducted amongst doctors working at medical institutions where abortions are conducted, found that a quarter of the respondents who refused to do abortions, would also not refer patients to other doctors. More disturbingly, $14 \%$ of the respondents said that they would not see abortion patients, even in cases of a medical emergency (Cape Argus 03.04.1998).

According to a study conducted by Poggenpoel, Myburgh and Gmeiner (1998: 4) nurses were angry because they were not consulted about their opinions regarding abortion prior to the introduction of the new legislation. The majority of nurses refused to participate in caring for patients opting for abortions. Furthermore, many of these nurses indicated that they would rather leave nursing than be forced to assist with TOP patients. Many of them felt that both the women undergoing the TOP and the staff providing this service were murderers.

Antipathy towards the Act may lead health care workers to not merely exercise their constitutional right to conscientious objection, but to go beyond and exert subtle or even illicit pressure to impede legitimate access to abortion. Opposition to abortion can easily be camouflaged behind the veil of limited health care resources. Health care workers who support abortion and the Act could find themselves condemned, ostracised or even victimised by their colleagues. Equally, women who opt for abortion may be faced with antipathy and stigmatisation from within the health care setting itself, let alone the wider community. In short, the possibility of health workers becoming an impediment to the smooth implementation of the Act should not be overlooked.

While the Act reflects the intention to make TOP accessible to all South African women, it cannot by itself ensure or guarantee equitable access. The Act assumes that health care providers will give effect to the legislative intention, but giving practical meaning to such intention, can be problematic. Whilst a substantial number of TOPs have already been performed in terms of the new Act, it has also surfaced that an array of factors of various kinds (e.g. health care workers who are hostile to wumen who access abortion, unavailability of staff, inadequate facilities, etc.), may impede its further implementation and operation (Reproductive Rights Alliance 1997: 1-11; 1998: 3-14). Notwithstanding any impediments, however, from February 1997 to July 1998,61384 TOPs were conducted through- out South Africa (Reproductive Rights Alliance 1998: 5-19). By far the majority of TOPs in South Africa have been conducted in Gauteng ( $30491 ; 49,7 \%)$, followed by the Western Cape ( 8 $507 ; 13,8 \%)$. Free State $(5973 ; 9,7 \%)$ and Eastern Cape (5 $538 ; 9,2 \%)$.

\section{Planning the current study}

The existence of numerous impediments to the Act were established in a consultation and workshopping process in April 1997 , which was attended by a variety of role players and interest groups to discuss the implementation and operation of the Act in the Free State. Issues such as the following were raised:

- $\quad$ The fact that personnel volunteered to participate did not automatically imply that they were not emotionally affected by the trauma of abortion itself or the negative attitudes of certain colleagues towards them.

- $\quad$ Other health providers in the province, even if they opted not to be involved in TOP or declared themselves opposed to TOP, were still expected to at least refer patients to TOP facilities. This, in itself, represented a moral dilemma and may have caused some of them to blatantly refuse to cooperate or find some clandestine way of sabotaging the referral procedure.

- $\quad$ Some health workers displayed hostile attitudes towards those involved in TOP, both health professionals and the women involved alike.

Emanating from this initial workshopping process and literature study, the main categories of impediments to the Act were classified as user and provider/service factors. Examples of user factors included partners, friends and the community that are hostile to women who access abortion; problems such as transport, distance, poverty and accommodation that place an abortion facility beyond the reach of women; and a lack of knowledge about abortion services. Provider/service factors included unavailability of staff, unskilled or incompetent staff, poor staff morale, hostility of staff towards women accessing abortion services, hostility of staff towards colleagues involved in abortion services, and poor or inadequate physical facilities.

\section{Aim and objectives of the study}

The project focused on the identification of problems, constraints and impediments encountered in the process of implementing the Choice on Termination of Pregnancy Act in the Free State. An integral part of this process will be the development of a provincial strategy to assist policy-makers, managers and health providers in overcoming the above problems, constraints and impediments. Such a strategy will be based on the project management approach, and will have a specific TOP facility, as well as broader provincial application. The core objectives of the project were:

- To identify and explicate possible social, cultural,

attitudinal, infrastructural and service impediments, as well as factors that facilitate the implementation and operation of the Act, by means of consultation and survey research.

- $\quad$ To devise a project management strategy for policy makers, managers and service providers to overcome such impediments and to ensure equity in access to quality TOP services in the Free State.

- $\quad$ To apply and implement the strategy over a three month period.

- To critically monitor the success of the strategy opted for throughout the implementation process, within a 
process that will culminate in a workshop attended by Department of Health representatives

(policy-makers, managers and health providers) from both the Free State and all other provinces to review strategic options for the way forward.

\section{Methodology}

The project contained three distinguishable phases.

- A finding out phase comprising consultation and survey research amongst both providers and users of TOP services, as well as health professionals in general, to determine the nature and extent of impediments to TOP (completed).

- A planning phase to design a project management strategy for the province and for specific TOP service facilities to overcome impediments to the provision of TOP services (in progress)

- $\quad$ An implementation phase during which the above-said strategy is implemented and monitored and which will be followed by a feedback workshop also to be at tended by representatives from other provinces (primarily Department of Health officials responsible for planning, managing and delivering TOP services (pending)

As the planning phase is still in progress and the implementation phase is pending, the remainder of this article will profile the main findings of the finding-out (survey) phase of the project only.

\section{The finding out phase}

The finding-out phase comprised two main activities, namely a consultation process and a survey research process. During the consultation process, in-depth, unstructured interviews were conducted with two senior officials from the Department of Health and information was obtained from TOP service providers during meetings and site visits. Issues that were addressed during the interviews included problems experienced with the implementation of the Act; successes at the TOP facilities; attitudes of colleagues towards TOP staff; the importance of the TOP Act; training of midwives and counsellors; problems surrounding counselling; availability of support for TOP staff; and suggestions for the smooth running of TOP facilities. Information that was gathered during the consultation process was used to compile questionnaires for the survey.

The survey was conducted at the three public health facilities in the Free State providing TOP services, namely the Elizabeth Ross Hospital in Phuthaditjhaba, the Kopano Clinic in Welkom and Pelonomi Hospital in Bloemfontein. The survey was conducted amongst:

- women who had undergone a TOP since the implementation of the Act $(n=75 ; 25$ users from each facility);

- $\quad$ health professionals and social workers who provide TOP services $(n=16)$; and

- health professionals and social workers who are in a position to refer women to TOP facilities $(n=63)$.

\section{Data collection among women who had undergone TOP}

Three female interviewers were carefully selected and then trained over a two day period to conduct the fieldwork. Crite- ria for the selection of fieldworkers included African women between the ages of 25 and 35 years with a nursing/paramedical background and who are sensitive, non-judgemental, able to converse fluently in SeSotho and English, and have a valid drivers' license. The first day of training entailed teaching the fieldworkers interviewing techniques, familiarising them with the questionnaire, informing them about abortion and how to deal with sensitive issues in the questionnaires. The second day of training was facilitated by two representatives from the Free State Department of Health and entailed looking at ethical aspects pertaining to abortion. This included a discussion and clarification of conventional "pro-life" and "pro-choice" arguments to familiarise fieldworkers with the broader context surrounding the issues of abortion. Furthermore, fieldworkers were advised on how to be empathetic with clients without being judgmental. Finally, the stipulations of the Act with regard to the role and obligations of health workers were explained to the fieldworkers.

Survey research is always subject to voluntary participation and as such, no respondents were compelled to participate in this study. In particular, survey research related to a topic as sensitive as abortion brings to the fore a number of specific ethical considerations. Therefore, the survey was conducted in such a way that no harm should have come to the respondents. Accessing the users who had undergone TOP was especially problematic. The very act of approaching them to obtain their permission to involve them in the survey, could have caused distress. The fieldworkers therefore sought to minimise harmful impact on these women. The fieldwork process involved close co-operation with the three facility managers, who were responsible for providing the fieldworkers with names of potential interviewees who had consented to participate in the interview. The only criterion for selecting interviewees was that they must have had an abortion and not still be at the pre-counselling stage. The reason for this was that it could hardly be hoped to validly evaluate the effectiveness and efficiency of the Act, if the users' experience of the entire procedure was not taken into account. Clients were informed about the research by the registered nurse/social worker providing pre-counselling and asked whether or not they would like to participate in such a project. Only the names of those clients who agreed to participate in the study were then given to the fieldworker, who contacted the potential interviewee. The fieldworkers arranged to meet the interviewee at a time and place that was convenient for her. This ensured that the interviews were conducted with the informed consent of the interviewer in a confidential manner and in a setting that respected privacy and encouraged truthful reflection. The fieldworkers were trained not to carry any type of stress into the interview. Interviewees were afterwards compensated for their time and travelling costs.

Although there are limitations associated with the self-selection of respondents, it was deemed advisable by the researchers that in a study focussing on an issue as sensitive as abortion, potential interviewees should first be informed about the research and then be asked to participate. This was an attempt to minimise any distress that may result from being interviewed about such a private and confidential matter. Although self-selection of this nature does allow for some degree of bias to be carried into the research, this was the most appropriate sampling strategy for reasons already mentioned. In an attempt to ensure objective responses the questions were formulated and asked in as neutral a way as possible.

\section{Data collection among health care providers and social workers}

Self-administered questionnaires were developed for use 
among health professionals and social workers who provide TOP services and health professionals and social workers who are in a position to refer women to TOP facilities. The questionnaires were dropped off at the facilities where the respondents worked and were then later collected on a date that had been specified by the researcher. In the case of health care providers and social workers providing TOP services, the TOP facility manager acted as the contact person, and co-ordinated the distribution and col-

lection of questionnaires. All respondents working at the TOP facilities were included in this survey. With regard to health care providers and social workers who are in a position to refer clients to TOP facilities, the TOP facility managers provided the researches with detailed lists of such persons, who were also all targeted to act as respondents. All respondents were ensured that any information they provided would be kept confidential.

\section{The research instruments}

The questionnaire used for the interviews with women who had undergone a TOP, as well as the self-administered questionnaires that were used for TOP service providers and health care professionals who referred patients to TOP facilities, were developed in close co-operation with members of the Free State Department of Health and TOP service providers to ensure that the items were indeed measuring what they were supposed to measure. During the fieldworker training, the questionnaire for women who had undergone a TOP was tested on a TOP client and on TOP service providers. The questionnaire was adapted to accommodate suggestions. Once the fieldworkers had each done three interviews, the fieldwork process was halted to check the questionnaires and discuss any problems. Throughout the fieldwork process the questionnaires were checked for completeness and accuracy. Close co-operation with TOP facility managers, the fieldworkers and feedback from respondents ensured that all the interviews had indeed been conducted.

The questionnaires developed for use among health professionals and social workers who provide TOP services and health professionals and social workers who are in a position to refer women to TOP facilities, were developed in collaboration with officials from the Department of Health.

\section{Problems experienced}

Many problems were experienced in gaining access to interviewees. The problem that resulted in the longest delay in the fieldwork, was that clients were difficult to reach as many of them did not have telephones at home. Further problems that were experienced were that false names were given, as well as incorrect telephone numbers and addresses. The counsellors also reported that quite a number of clients refused to participate in the study. No problems were experienced with gathering information from the providers. However, numerous problems surfaced with staff at referring facilities. Most prominent of these was the fact that some doctors were of the opinion that they should be paid for completing the questionnaires. In addition, questionnaires were not completed by the collection date. one response.

\section{Findings of the user survey profile of respondents}

The user sample consisted of 75 women, 25 from each of the three public facilities in the Free State (Pelonomi Hospital, Kopano Clinic and Elizabeth Ross Hospital) providing TOP services. An attempt was made to select women proportionately from various age groups so as to be representative of the entire population of women utilising services at these three facilities. The age breakdown for the sample is given in table 1. With regard to the marital status of the women, more than half $(N=52 ; 69,3 \%)$ were unmarried; $21,3 \%(N=16)$ were married; $4 \%(n=3)$ were widowed; $2,7 \%$ were separated; $1,3 \%$ were divorced; and $1,3 \%$ were living together. More than a quarter of the respondents were unemployed $(\mathrm{N}=24 ; 32 \%)$ (excluding students) while almost half of the respondents were students/pupils ( $N=33 ; 44 \%$ ). The overall economic profile of the users is thus one that reflects a high degree of financial deprivation. This inevitably corresponds with the reasons mentioned for having an abortion (see table 2).

\section{Reasons for deciding to have a TOP}

Although reasons for having a TOP varied from facility to facil-

\section{Table 2 : Reasons for abortions}

\begin{tabular}{llc}
\hline Reasons & N & $\%$ \\
\hline Financial problems (unemployed or a student) & 39 & 34,5 \\
Personal problems/external motivations (e.g., continue with studies) & 28 & 24,8 \\
Relationship problems (e.g. partner is married to another women) & 24 & 21,2 \\
Family related motivations (e.g., already have a large family) & 22 & 19,5 \\
\hline
\end{tabular}

Note, frequencies and percentages reflect the total number of responses rather than the number of responses, this has been done in order to capture more than

ity, from table 2 it can be deduced that socio-economic reasons played the dominant role. Financial problems were one of the major causes for respondents from Kopano Clinic deciding to have a TOP $(\mathrm{N}=14 ; 56 \%)$ compared with respondents from Elizabeth Ross Hospital $(\mathrm{N}=2 ; 8 \%)$. Financial problems $(\mathrm{N}=8 ; 32 \%)$ and relationship problems $(\mathrm{N}=8 ; 32 \%)$ were the main causes for TOP among respondents from Pelonomi Hospital. Personal problems were a stronger reason for deciding to have a TOP among Kopano Clinic's respondents $(\mathrm{N}=14 ; 56 \%)$ than amongst Pelonomi Hospital's respondents $(N=5 ; 20 \%)$ and Elizabeth Ross Hospital's respondents $(N=2$; $8 \%$ ). 


\section{Evaluation of treatment and services at TOP facilities}

Generally the respondents were treated well by staff at the reception desk ( $\mathrm{N}=50 ; 66,7 \%)$, nurses $(\mathrm{N}=66 ; 88 \%)$, doctors $(N=61 ; 81,3 \%)$, counsellors $(N=56 ; 76,7 \%)$, and by other patients $(\mathrm{N}=52 ; 69,3 \%)$. While all of the respondents at Pelonomi and Elizabeth Ross indicated that they were well treated by the doctors, only 11 respondents $(44 \%)$ at Kopano said the same. The remaining 14 respondents (56\%) at Kopano stated that they had not seen doctors. Respondents at Pelonomi $(\mathrm{N}=24 ; 96 \%)$ and Elizabeth Ross $(\mathrm{N}=22 ; 88 \%)$ were also more satisfied that they had been treated well by the counsellors, than the respondents at Kopano $(\mathrm{N}=10 ; 40 \%)$. In fact, 13 respondents $(52 \%)$ from Kopano reported that they had not seen the counsellors. In almost all of the cases the respondents had not really come into contact with the security guards (Pelonomi $\mathrm{N}=16,64 \%$; Elizabeth Ross $\mathrm{N}=24$; 96\%; Kopano $N=11 ; 44 \%$ ) and cleaners (Elizabeth Ross $N=25 ; 100 \%$ ). Respondents from Pelonomi ( $N=18 ; 72 \%)$ and Kopano $(\mathrm{N}=12$ $48 \%$ ) indicated that they were well treated by the cleaners Furthermore, the respondents were asked a number of questions to evaluate the services offered by the TOP facilities. Firstly, they were questioned about their level of satisfaction with a number of services that are a prerequisite when going for a TOP The respondents were generally satisfied with the services that they had received at the TOP clinic: pre-counselling $(\mathrm{N}=54 ; 72 \%)$; examination ( $\mathrm{N}=69 ; 92 \%)$; procedure ( $N=$ $68 ; 90,7 \%)$, TOP information ( $N=69 ; 92 \%)$ and contraceptive information ( $N=67 ; 89,3 \%)$. It is, however, of concern to note that post-counselling was not available for $48 \%$ of the respondents $(\mathrm{N}=36)$ and also that pre-counselling was not available for $21,3 \%$ of the respondents $(N=16)$.

Both pre- and post-counselling were problem areas for the respondents at Kopano Clinic as 15 respondents $(60 \%)$, in both cases, stated that this service was not available. Post-counselling was also lacking at Pelonomi Hospital, as reported by 11 respondents $(44 \%)$. While $76 \%$ of the respondents $(N=57)$ had received counselling prior to the termination an alarming $24 \%$ had not $(\mathrm{N}=18)$. Only one respondent from Pelonomi and Elizabeth Ross had not received pre-counselling, while 16 from Kopano Clinic $(64 \%)$ had not receive pre-counselling. It is of concern to note that more than half of the respondents had not received counselling after the termination ( $N=42 ; 56 \%)$.

\section{Emotional reactions to TOP and support}

With regard to the emotional experience of the respondents, prior to the termination, more than a third of the respondents $(N=30 ; 36,6 \%)$ felt depressed, unhappy and ashamed. Many of the respondents $(N=18 ; 19,4 \%)$ were also worried. Only 8 respondents $(8,6 \%)$ indicated that they felt good about the termination. During the termination procedure, almost $40 \%$ of the respondents $(N=26 ; 39,8 \%)$ indicated that it was very painful. Despite this pain, many more respondents $(\mathrm{N}=33$; $37,5 \%$ ) reported experiencing positive feelings once the procedure was under way. Upon completion of the TOP procedure more than half of the respondents $(N=57 ; 62,9 \%)$ indicated that they were satisfied, and happy that everything would soon be back to normal. Despite this, many respondents also felt guilty, ashamed $(\mathrm{N}=24 ; 24,7 \%)$ and were sorry for what they had done $(\mathrm{N}=7 ; 7,2 \%)$.A considerable proportion of clients suffered from emotional feelings usually associated with depression and/or self-reproach - both before $(N=43 ; 46,3 \%)$ and after the procedure $(\mathrm{N}=31 ; 31,9 \%)$. This is captured in expressions like the following (before the procedure)

I felt sad because it was not planned and the father decided to leave me; I was very depressed and worried; I was very depressed and was battling with my emotions as to whether I should terminate or not.

Clients' feelings after the procedure were described as: I've been feeling very guilty about what / did; I am happy but I am also ashamed of myself; I was very tearful and experienced a great sense of loss

It appears as if many of the respondents attempted to deal with the abortion on their own. This becomes evident when only more than a third of the respondents $(N=29,38,7 \%)$ indicated that they had discussed the intended termination with a family member. The reasons why 46 respondents $(61,3 \%)$ had not discussed this with a family member were expressed in phrases such as:

I was afraid of their response $(N=20)$; I wanted it to be a secret I didn't want to tell them (N=14); I don't live with them $(N=5)$; they are all younger than me $(N=4) ;$ I am only living with my partner/husband $(N=2)$; / was embarrassed $(N=1)$

\section{Knowledge of TOP AC†}

In order to determine how much the respondents knew about the Act, they were asked to respond to a number of true and false statements. The average of correct responses for all five questions was $47,2 \%$ indicating that the respondents were not that well informed about the Act. This conclusion is in fact also underlined by the relatively high proportions who were

\section{Table 3 : Respondents' recommendations to facilitate the process for women considering TOP}

\begin{tabular}{lcc}
\hline Recommendations & N & $\%$ \\
\hline The entire TOP procedure should be done at clinics/hospitals and not alone at home & 18 & 30,0 \\
Information on TOP Act and/location of TOP facilities & 13 & 21,7 \\
More accessible services (arranging transport and/accommodation, bigger facilities, more facilities, & 8 & 13,3 \\
more doctors, know it is for free) & 6 \\
More trained/professional staff & 10,0 \\
There should be strict requirements for who qualifies for TOP so that it is not used as a contraceptive method & 4 \\
Women and especially teenagers should be taught about contraceptives & 6,7 \\
Patients should be given medication for pain relief & 5,0 \\
Minors should have consent from parents & 3,3 & 2 \\
\end{tabular}


"uncertain". (To a certain extent the uncertain responses should be treated as "incorrect" answers, thus a lack of knowledge.) However, they were better informed about issues such as their partner not having to give permission for the TOP to be conducted $(\mathrm{N}=49 ; 65,3 \%)$ and that TOP is available after the twentieth week if the continued pregnancy would endanger the life of the woman $(N=37 ; 49,3 \%)$.

\section{TOP a future option?}

The vast majority of respondents ( $N=67 ; 89,3 \%)$ stated that they would not consider having another TOP. Reasons why the 8 respondents would consider having another TOP included not wanting another child $(\mathrm{N}=3 ; 4,1 \%)$ and being unmarried $(\mathrm{N}=3 ; 4,1 \%)$. The Reasons why they would not have another TOP included the intention to use contraceptives and plan $(N=40 ; 54,1 \%)$; the fact that they suffer from negative feelings such as guilt $(\mathrm{N}=9 ; 12,2 \%)$; and the procedure was too painful $(\mathrm{N}=8 ; 10,8 \%)$.

\section{Table 4 : Occupational categories}

\begin{tabular}{lcc}
\hline Occupational categories & Actual sample & Ideal sample \\
& N & N \\
\hline TOP facaility manager & 3 & 3 \\
General practitioner & 4 & 6 \\
Registered midwife & 5 & \\
Registered nurse & 1 & 9 \\
Staft nurse & 2 & 6 \\
Counsellor & 1 & \\
\hline
\end{tabular}

\section{Recommendations}

Respondents were asked to suggest strategies that will make it easier for women wanting a TOP. Their recommendations are listed in table 3 . The most frequently mentioned recommendations were that the entire TOP procedure should be performed in a health care environment $(N=18 ; 30 \%)$. This would mean that women would no longer have to have inductions at home; instead they would be under the constant supervision of health care staff. This would reduce the risk of complications and perhaps even reduce the psychological trauma of disposing with the products of conception. A further recommendation was that there needed to be more information on the TOP Act and on the location of TOP facilities.

\section{Findings of the provider survey occupational categories}

Sixteen TOP service providers participated in this survey - five from Pelonomi hospital, five from Kopano Clinic and six from Elizabeth Ross Hospital. Due to the relatively small number of participants only $\mathrm{N}$ values will be reflected, and not percentages, in this section. The occupational categories of these service providers are given in table 4.

The fact that there was only one respondent in the category for counsellors can be ascribed to the fact that some midwives also act as counsellors. Such service providers are thus fulfill- ing a two-fold role, but completed the questionnaires in their capacity as midwives.

\section{Evaluation of services and facilities}

Most of the respondents rated all of their services as being good, however, post-care of TOP patients needs to receive attention. This can partially be ascribed to the fact that many clients did not come back for follow-up care and this was also one of the areas pointed out by the clients. Post-counselling services in particular, seem to be non-existent in many cases, as $48 \%$ of the clients reported that this service was not available.There was much dissatisfaction with the physical aspects of the TOP facilities, especially with regard to the consultancy rooms which were either insufficient (Kopano $=3$, Elizabeth Ross $=3$ ) or non-existent (Pelonomi $=4$ ) and counselling rooms which in all cases were insufficient (Pelonomi $=5$, Kopano $=3$, Elizabeth Ross $=3$ ). Visual and auditory privacy was a problem at Pelonomi (visual $=4$, auditory $=3$ ), while only visual privacy was a problem at Elizabeth Ross $(\mathrm{N}=3)$. Staff restrooms were non-existent at the three facilities (Pelonomi=4, Kopano=3, Elizabeth Ross $=4$ ) and office space was non-existent at Pelonomi $(\mathrm{N}=4)$ and insufficient at Kopano $(\mathrm{N}=2)$ and Elizabeth Ross $(N=3)$.

\section{Attitudes towards TOP}

The attitudes of these service providers towards TOP are presented in table 5 . It is evident that generally the respondents had a fairly positive attitude towards TOP. In a few cases respondents differed rather vehemently in their views. These mainly pertain to the unqualified justification of TOP and preservation of human life, as well as the role of religious and social/financial problems with respect to TOP (See items 2, 3, 7, 9 in table 5). Respondents were strongly divided in their opinions $- \pm 50 \%$ were agreeing with the statement, while the rest either disagreed or took a position of uncertainty. The majority of the respondents $(N=14)$ felt positive towards the law allowing TOP on request during the first 12 weeks of pregnancy. Two respondents did, however, indicate that they felt uncertain about this new law. This appears to go hand in hand with the fact that 11 respondents indicated that their work morale was good, while three respondents indicated that they had a poor work morale and two were uncertain about this.

\section{Psychological/emotional support}

As illustrated in figure 1 , in most cases $(\mathrm{N}=8)$ there was no psychological/emotional support available for the staff providing TOP services, while four respondents said support was available at their facility and two respondents stated that support was available but not at their facility. Of the respondents who indicated that support was not available $(\mathrm{N}=8)$ or that they were uncertain $(N=2)$, eight indicated that they would like support to be available, while two said no. The types of support that they wanted included: stress management $(\mathrm{N}=3)$, the opportunity to talk to someone when necessary $(\mathrm{N}=3)$ and psychological help $(\mathrm{N}=2)$. This support should be available

* The TOP facility at Palonomi Hospital was moved to National Hospital early in November 1998. Overall this move has meant a big improvement in the facility structure, with more counselling rooms, better equipment, more privacy for the patients, a reception area and a waiting room, a tearoom for the staff and 14 beds of only three which they had a Pelonomi at the time of the study. 
1. TOP should not be legal

2. I believe TOP is justified under all circumstances

2

3. It is our moral and ethical responsibility to preserve human life, irrespective of any circumstances

4. A women has the right to make her own decisions concerning her body

5. TOP should be an alternative when contraceptives fail

6. People would support the right of women to have a TOP if they knew more about it

7. My religion does not prevent me from accepting TOP

8. Persons under 18 years of age should first obtain the consent of their parents before being allowed a TOP

9. Social and financial problems are sufficient reasons for requesting a TOP 10. Now that the grounds for TOP have been extended, people will become careless about their contraceptive practices

11. A women should only be allowed to have a TOP if her partner agrees

12. The foetus should have the same rights as the mother

13. Only the woman has the right to decide whether to have a TOP

14. Women do not need to feel ashamed if they decide to have a TOP

9 \\ 9}

6

13

12

12

8

2

8

7

1

4

11

13
12

4

8

3

2

2

0

3

4

5

3

2

3

0

3

2 from psychologists $(N=4)$, nurses $(N=1)$, colleagues $(N=1)$, management of the Department of Health $(\mathrm{N}=1)$ and priests $(N=1)$. With regard to available support, four respondents made use of this and three respondents indicated that this support came from psychologists.

\section{Abortion Values Clarification Workshop}

Nine of the respondents had attended an Abortion Values Clarification Workshop, while seven respondents had not. Eight respondents found it to be very useful while one respondent reported that it was of limited use as there was not enough time for exercises. Those who had found it to be useful said so because:

It had given them a better understanding of abortion (see it in a new way/ listen to different opinions) ( $N=6)$; She/he could apply what she/he had learnt ( $N=1)$; It had helped her/him to determine her/his feelings about abortion $(N=1)$;

The workshop had changed four respondents' attitudes towards abortion, and left the attitudes of the remaining five respondents unchanged. These respondents' attitudes appeared to have become more positive towards TOP; this can be seen in their responses:

The legal aspects became clearer and / accepted the TOP Act $(N=2)$; I learnt that women have the right to make their own decisions $(N=1)$; I realised it is not my decision, it is the clients' decisions ( $N=1)$

Eight respondents reported that the workshop had improved their effectiveness in dealing with TOP users, while one respondent reported it had not as she/he did not gain anything from the workshop. The effectiveness of the other eight respondents had improved in the following ways:

$A$ better understanding of TOP clients and their needs $(N=6) ;$ I feel more comfortable with myself $(N=1)$; / can reason with people who are against abortion $(N=1)$

\section{Problems experienced by counsellors}

In most cases, registered midwives were providing counselling for TOP clients. The problems experienced by these counsellors included the following:

Cultural problems (ignorance about contraceptives, overpowering male partners); Inadequate counselling facilities; Coun- selling style of no follow-up; Clients who are secretive/afraid to talk; Clients won't consider other options; Language problems; Procedure after inductions is difficult for clients; Clients who are more than 20 weeks pregnant, and how to help them

Counselling is a problem as there are not enough resources and time to adequately offer this service. Post-counselling should be offered at another venue, and not at the TOP facility. Patients do not want to come back to the facility, there is stigmatisation and a lot of personal reasons why she does not want to come back (personal interview).

\section{Reactions of co-workers to TOP}

Four of the 11 respondents stated that their work with TOP clients has affected their professional relationships with colleagues who now have negative attitudes towards them. However, 10 respondents stated that they had never been harassed by colleagues not doing TOPs. A few respondents $(\mathrm{N}=3)$ indicated that they sometimes felt guilty about doing TOPs and that in their opinion. TOP should not be within the scope of practice of a registered nurse.

\section{Recommendations}

The respondents made a number of recommendations regarding the smooth functioning of TOP facilities. The most frequently mentioned recommendations were the need for more trained staff $(N=10)$ followed by the need for adequate and accessible facilities $(N=6)$. This correlates with the evaluation of the structure of the facilities, where much dissatisfaction was expressed. Furthermore, the need for emotional support for staff, was once again mentioned $(N=4)$. Suggestions for a better service included better facilities, a 24 hour service, trained registered midwives, doctors on standby to deal with problems that may arise, the availability of a sonar to check the duration of the pregnancy, support services for personnel, and more involvement from managerial staff.

\section{Findings of the referral survey profile of persons doing referrals}

Health care workers in positions to refer clients to TOP facilities in fourteen Free State towns, were targeted in this survey. 


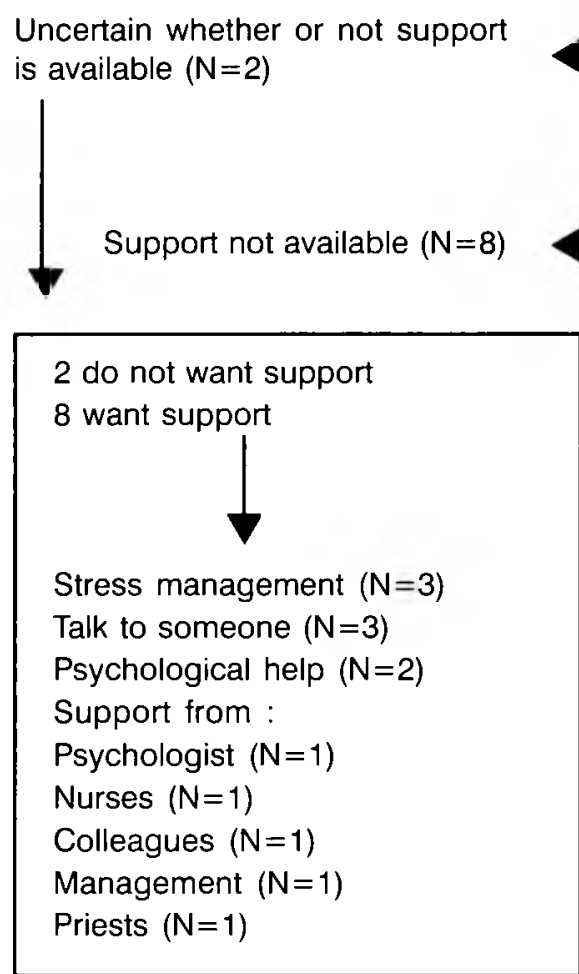

Note, frequencies reflect the total number of responses. So as to capture more than one response.
Support available at my facility $(\mathrm{N}=4)$

Support available but no at my facility $(\mathrm{N}=2)$

Type of support :

Psychological $(\mathrm{N}=4)$

Stress management $(\mathrm{N}=1)$

Comments :

Inadequate, as it is a new service $(N=1)$

4 use this service

2 do not use service

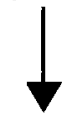

Only for nurses $(\mathrm{N}=1)$

Just starting $(\mathrm{N}=1)$

Support from :

Psychologist $(\mathrm{N}=3)$

TOP management $(\mathrm{N}=1)$
The TOP facility managers were asked to provide lists of clinics/doctors/health care workers who referred patients to their facilities. Almost all of the persons/clinics on these lists were targeted in the referral survey. More than half of the respondents were employed at clinics ( $N=34 ; 54 \%$ ), followed by $30,2 \%$ $(N=19)$ who were general practitioners in private practice. The majority of respondents were general practitioners $(N=27$; $42,9 \%)$ and registered nurses $(\mathrm{N}=27 ; 42,9 \%)$ and had been working as health care providers for more than seven years $(N=40 ; 63,5 \%)$.

\section{Attitudes towards TOP}

The respondents appeared to be very divided in their attitudes towards TOP. It is in fact quite evident that TOP implicitly entails a number of highly contentious issues, causing wide-ranging differences in opinion among health care workers. While $45,9 \%(N=28)$ felt that TOP should be legal, $41 \%(N=25)$ felt that TOP should not be legal. Slightly more than half of the respondents ( $N=32 ; 53,3 \%)$ indicated that TOP is justified under all circumstances. Despite this. $64 \%(\mathrm{~N}=39)$ said that it was their moral and ethical responsibility to preserve human life, irrespective of any circumstances. Furthermore, there was a division in the respondent's opinions concerning social and financial reasons being sufficient cause to allow a TOP, with $46 \%(N=29)$ in favour of and $47,6 \%(N=30)$ against social and financial grounds. It was clear, that $64 \%$ of the respondents $(\mathrm{N}=39)$ did not agree that TOP was an alternative when contraceptives failed. The issue of TOP being used as a contraceptive method, was clearly a concern for many respondents as $61,3 \%(N=38)$ felt that as the grounds for TOP had been extended, people would become careless about their contra- ceptive practices. It is apparent that most of the respondents doing referrals felt that TOP was an important human right $(\mathrm{N}=36 ; 72 \%)$, even if it is only under certain conditions. Those respondents $(\mathrm{N}=14 ; 28 \%)$ who were not of the opinion that TOP is an important human right, mainly felt this way due to moral, ethical and religious reasons as well as the fact that contraceptives are freely available. This support for TOP as an important human right, can also be seen in the responses of $33(52,4 \%)$ respondents who stated that they felt positive about abortion on request during the first 12 weeks of pregnancy. The fact that 24 respondents $(38,1 \%)$ felt negative about abortion on request during the first 12 weeks of pregnancy, must not be ignored - it is a rather high proportion. Furthermore, 34 respondents $(54 \%)$ indicated that they felt comfortable referring patients to TOP facilities, while 26 respondents $(41,3 \%)$ did not feel comfortable to do so.

\section{Abortion Clarification Workshop}

Only nine $(14,3 \%)$ of the 63 respondents had attended an Abortion Values Clarification Workshop. While eight of these respondents had found this workshop to be very useful, one respondent indicated that it was of limited use. Eight respondents indicated that their effectiveness in dealing with TOP users had improved since they attended the workshop, while one respondent said that her effectiveness had not improved. As in the case of the provider survey, it therefore seems that attendance of such workshops can be of paramount importance in breaking down negative perceptions of and prejudices against TOP in general and the Act in particular. 


\section{Referral of patients to TOP facilities}

More than half of the referral respondents $(\mathrm{N}=34 ; 54 \%)$ indicated that in future they would be willing to refer patients unconditionally to TOP facilities, 17 respondents $(27 \%)$ said depending on the circumstances, and 12 respondents (19\%) indicated that they would not refer a patient in future. The circumstances that would allow the respondent to refer a patient included:

Mental retardation, rape, incest, etc. $(N=7)$; If it is her decision to have the abortion $(N=4)$; If the duration of the pregnancy is not further than what is legally allowed ( $N=3$ ); If she can be sent to a well known facility and be treated under supervision $(N=1)$

The reasons why the respondents would not refer such a patient included:

Personal reasons (religion, morals, etc.) ( $N=9$ ); Contraceptives are available $(N=1)$; Abuse of the system, one woman has already had three TOPS $(N=1)$

\section{Conclusion}

Far more problems were identified by service providers and referral staff than by users during the survey. Overall the users were concerned with the lack of post-counselling and to a lesser degree the lack of pre-counselling. Furthermore they recommended that inductions should be conducted at the TOP facility and not at home. The problems highlighted by providers and staff doing referrals can be categorised into three categories:

- $\quad$ problems relating to the poor referral system (health are providers who do not want to refer clients to TOP facilities)

- problems relating to communication, information and empowerment (lack of counselling for clients, no psy chological/emotional support for TOP service providers, TOP was not accepted by all health care providers); and

- problems relating to resources and infrastructure (inductions should be done at TOP facilities, dissatisfac- tion with the physical structure of TOP facilities, too few staff members, problems with equipment)

Factors that have facilitated the functioning of TOP facilities included: friendly treatment of users by TOP service providers; provision of "good" services; positive attitudes of TOP service providers; Abortion Clarification Workshops; The challenge is now to integrate and enhance strengths to address these weaknesses in the present system. This is being done in conjunction with relevant members of the Free State Department of Health during the planning phase of the research Once a strategy has been developed it will be implemented at a TOP facility in the Free State over a three month period (implementation phase). During this time the strategy will be evaluated and monitored in order to address any problems. At the end of this process a national workshop will be held, during which feedback will be given to other provincial departments of health where the Free State experience can be discussed and critically analysed in an attempt to assist other provinces which are struggling with similar problems.

\section{Acknowledgements}

The researchers gratefully acknowledge the financial support from the Reproductive Health Fund (HST) and logistical support from staff at the three facilities and at provincial and regional head offices. 


\section{Bibliography}

Choice on Termination of Pregnancy Act, 1996. (Act No 92 of 1996.

Cape Argus, 1998. Abortion legal - but still a minefield. 3 April 1988.

Editorial. 1997. Backstreet abortion in South Africa. South African Medical Journal, 87(4), 417.

Felder, J. 1993. A matter of choice; abortion and law reform in apartheid South Africa. Pietermaritzburg: Hadeda Books.

Goosen, M. \& Klugman, B. (eds) 1996. The South African Women's Health Book. Cape Town: Oxford University press.

Hardy, W., Gilpin, T., Stead, M., van Andel, P. \& Somasumeran, A. 1996. Abortion legislation. South African Medical Journal, 86(11): 1433.

Hanson, D., \& Russel, D.E.H. 1993. Made to fail: The mythical option of abortion for survivors of rape and incest. South African Journal on Human Rights, 9(4), 500-24.

Ngwena, C. 1998. The history and transformation of abortion law in South Africa. Acta Academica, 30(2), 32-64.

Poggenpoel, M., Myburgh, C.P.H., \& Gmeiner, A.C. 1998. One voice regarding the legislation of abortion nurses who experience discomfort. Curationis, $21(3), 2-7$.

Reproductive Rights Alliance. 1997. Barometer, vol 1, Issue 1, $1-11$.

Reproductive Rights Alliance. 1998. Barometer, vol 1, Issue 2 , 3-14.

Reproductive Rights Alliance. 1998. Barometer, vol 2, Issue 1 , 5-19.

Sarkin-Hughes, J. \& Sarkin-Hughes, N. 1990. Choice and Informed request: the answer to abortion. Stellenbosch Law Review, 1(3), 372-87.

Strauss, S.A. 1991. Doctor, patient and the law. Pretoria: JL van Schaik.

SAIRR (South African Institute of Race Relations). South Africa Survey 1996/97. Johannesburg: South African Institute of Race Relations, 492.

The Star. 1996. Battle looms in parliament over pregnancy bill. 20 September 1996.

The Star. 1996. Countrywide protests over new abortion bill. 6 October 1996.

The Star. 1996. Bishops urge withdrawal of abortion law. 16 October 1996.

Walker, L. 1996. "My work is to help the woman who wants to have a child, not the woman who wants to have an abortion" Discourses of patriarchy and power among African nurses in South Africa. African Studies, 55(2): 43-67. 